\title{
CURRICULUM DESIGN FOR SPECIAL CONDITIONS BASED ON ISLAMIC VALUES: Study at Senior High School Al-Hikmah Boarding School Batu
}

\author{
Muhammad Fahmi Hidayatulah, "Muhammad Anwar Firdausi, ${ }^{\text {* }}$ and Muhammad \\ Hanief ${ }^{2}$ \\ * Universitas Islam Malang, Indonesia \\ ** Universitas Islam Negeri Maulana Malik Ibrahim Malang, Indonesia \\ E-mail: m.fahmihidayatullah@unisma.ac.id
}

\section{Abstract}

Covid-19 is a way for each educational institution to improve quality, processes, as well as facilities and infrastructure. The epidemic indirectly demands the education institution for adaptive and innovative new life accompanied by the development of information technology. The Ministry of Education and Culture has issued a curriculum policy for special conditions during the pandemic based on the circular regulation of the Minister of Education and Culture Number 719 of 2020. In addition, the issue of freedom to study in primary and secondary education institutions has emerged since 2019. Through the locus of Senior High School al-Hikmah Boarding School Batu, the researchers explored the data regarding the design of an independent curriculum based on Islamic values implemented since 2019. The curriculum has relevance to the Covid-19 special conditions curriculum and can be used as a model for the Covid-19 curriculum based on Islamic values. The research approach used is descriptive qualitative. While, the type of research is a case study with in-depth interview data collection, participatory observation, and documentation. It used an interactive data analysis through data collection, data presentation, data reduction, and conclusions. The results of this study indicate that the independent curriculum of al-Hikmah Boarding School Batu has relevance to 
the link and match-based special conditions curriculum. In addition, the independent curriculum contributes to shaping the learners' attitudes based on spiritual strength, nationalism, and mental leadership.

Covid-19 sebagai jalan bagi masing-masing lembaga pendidikan untuk meningkatkan mutu standar isi, proses, maupun sarana dan prasarana. Wabah secara tidak langsung telah menuntut lembaga pendidikan untuk adaptif dan inovatif terhadap kehidupan baru disertai perkembangan tekonologi informasi. Kemendikbud telah mengeluarkan kebijakan kurikulum kondisi khusus di masa pandemi berdasarkan edaran peraturan Menteri pendidikan dan kebudayaan nomor 719 tahun 2020. Selain itu isu tentang merdeka belajar di lembaga pendidikan dasar dan menengah muncul sejak tahun 2019. Peneliti melalui lokus SMA al-Hikmah Boarding School Batu menggali data tentang desain kurikulum mandiri berbasis nilai keislaman yang diterapkan sejak tahun 2019. Kurikulum tersebut memiliki relevansi dengan kurikulum kondisi khusus Covid-19 dan bisa dijadikan sebagai model kurikulum Covid-19 berbasis nilai keislaman. Pendekatan penelitian yang digunakan adalah kualitatif deskriptif. Sementara jenis penelitiannya adalah studi kasus dengan teknik pengumpulan data wawancara mendalam, observasi partisipatif, dan dokumentasi. Adapun analisis data penelitian adalah analisis data interaktif melalui pengumpulan data, penyajian data, reduksi data, dan penarikan kesimpulan. Hasil penelitian ini menunjukkan bahwa kurikulum mandiri al-Hikmah Boarding School Batu memiliki relevansi dengan kurikulum kondisi khusus berbasis link and match. Selain itu kurikulum mandiri berkontribusi membentuk sikap kesemaptaan peserta didik berdasarkan kekuatan spiritul, nasionalisme, dan mental kepemimpinan.

Keywords: curriculum design; Islamic values; special condition

Received: December 08, 2021; Accepted: December 30, 2021

\section{Introduction}

The epidemic has changed various circumstances and provided benefits for improving the quality of public services in various fields (World bank 2021), one of which is the world of education. The change in question is a shift in learning from traditional to conventional. This learning pattern is in line with the development of science and technology in the 21st century, namely the emergence of the term artificial intelligence, meaning artificial 
intelligence through simulations of human intelligence modeled by machines (Bird et al. 2020). Artificial intelligence emerged based on the results of research conducted by experts and scientists. During the Covid-19 era, the world is slowly adapting to this intelligence through education and teaching activities.

Adaptation of conventional learning has a positive and negative impact on education in the country. As stated by Prof. Nizam, Director General of Higher Education, Ministry of Education and Culture, the online learning evaluation survey result in May-June 2020 showed $70 \%$ said learning was considered good and very good. While, 30\% acknowledged the existence of weaknesses (I. Kamil 2020). The results of the SMRC survey in August 2020 demonstrated that $92 \%$ of students experienced many problems in online learning (SMRC 2020). Therefore, it is necessary to manage problems to reap multiple benefits by taking advantage of the pandemic as an opportunity to revive the national education through curriculum development.

The curriculum as a component of the national education system has a vital role in the development and progress of the institution (Suradi et al. 2021). The pandemic condition makes the curriculum an impacted component in carrying out its goals. Few educational institutions have lost control in carrying out their curriculum through teaching and learning activities. In the end, the Minister of Education issued a policy regarding guidelines for implementing the curriculum in Education units in special conditions or better known as the COVID-19 adaptive curriculum, which then appeared a joint decree regarding guidelines for the implementation of learning for the new academic year 2020/2021 during the coronavirus disease 2019 (Covid) pandemic. -19).

Covid-19 adaptive curriculum is an alternative curriculum in special circumstances such as the current pandemic conditions. The curriculum also provides an opportunity to develop the concept of independent learning in schools as the ideals that the Indonesian Minister of Education for 2019. 2024, Nadiem Anwar Makariem wants to realize. Meanwhile, four main independent learning policies for schools cover the zoning PPDB system, 1 sheet RPP, National Standard School Examination and Minimum Competency Assessment and Character Survey consisting of literacy, numeracy and strengthening character education. This freedom of learning is also an opportunity for institutions to develop their academic competencies during the pandemic. 
Schools with academic achievements and innovations have various ways of maintaining effectiveness and increasing learning productivity. For example, Senior High School al-Hikmah Boarding School Batu, East Java, Indonesia is a school that combines general education institutions and Islamic boarding schools. The learning system at the school is carried out for 24 hours, so it is not surprising if there is a physical test applied in the selection system for new students. In addition, Senior High School alHikmah Boarding School Batu also applies an independent learning curriculum through the Self Directed Learning (SDL) learning model. This learning presses students to take roles and initiatives to plan, choose learning resources, assess learning outcomes and motivate themselves based on the skills, and interests of students (Kunjcoro 2020).

Independent learning at Senior High School al-Hikmah Boarding School Batu through Self Directed Learning (SDL) by combining face-to-face and virtual face-to-face. Virtual face-to-face by maximizing the learning and content management system (LCMS) to increase their learning independence, so that not a few students in their first semester have studied the material for the second semester (Kunjcoro 2020). Therefore, the learning at this institution is adaptive to the Covid-19 conditions. What is also interesting about this institution is the apprenticeship learning program (alHikmah 2020), which collaborates between institutions and the world of work according to the current education model with the concept of link and match.

Based on the variety of uniqueness above, this study aims to collect data on three dimensions: independent curriculum design, the relevance of the independent curriculum to the special conditions curriculum, and the characteristics of the independent curriculum at Al-Hikmah Boarding School Batu. Highlighting Nasri's research, SDL supports the concept of lifelong learning and prepares skilled workers with the principle of freedom of learning to be a priority over educators designing learning strategies (Nasri, Halim, and Talib 2020). Also, it supports Razawi et al. on the concept of SDL by making students play an active role in learning, and SDL learning begins when students decide to organize and control their learning based on the teacher's instructions (Razawi et al. 2011).

\section{Method}

The paradigm used in this scientific article is the philosophy of postpositivism. In Sugiono's opinion, an attempt to view social reality as 
something holistic/whole, dynamic, complex, full of meaning, and interactive symptom relationships (Sugiono 2016, 14-15). While the approach used is qualitative-descriptive, which is directed at the background and the individual holistically (whole). In this case, it is not permissible to isolate individuals or organizations into variables or hypotheses, but it is necessary to view them as part of a whole (Moleong 2000, 4).

The type of research is a case study with a multi-case development design, which refers to an in-depth study of the description of an event that has occurred regarding the character and distinctive nature of an event (Bakri 2013, 58). The research focuses on extracting data and facts in the field based on events. Data collection techniques are carried out by in-depth interviews, active observation (participant), written documentation accompanied by internal criticism and external criticism, and focus group discussions (Bakri 2013, 127-35). Interviews were not carried out by the researchers considering the character in question had died, so in-depth observations were carried out through existing documentation, both books, print and online media. The qualitative data analysis technique using interactive data analysis consists of three components: data reduction, data display, and finally conclusion drawing/verification (Miles, Huberman, and Saldana 2014, 14).

\section{The Nature of the Curriculum Special Conditions: Independent Curriculum Hierarchy}

The special conditions curriculum issued by the Minister of Education of the Republic of Indonesia through Permendikbud No. 179 of 2020 dated 4 August. The definition of a special condition curriculum (Kemendikbud $2020,12)$ is the design of material/content or basic competencies in curriculum 13 and how to implement it in learning to achieve educational goals in conditions of disaster based on the determination of the Central and Regional Governments. Special condition curriculum encourages independent educational institutions to see the disaster as an indirect opportunity to make institutional human resources evolve creative ideas in carrying out learning activities during the emergency conditions.

The Minister of Education and Culture, Nadiem Anwar Makarim, on a virtual presentation of the adjustment of educational institution policies in conducting learning in the Covid-19 Pandemic Period, said "The curriculum in educational units in special conditions provides flexibility for schools to choose a curriculum that suits their needs. student learning" (Tempo 2020). It means the government opens the door as wide as possible for educational 
institutions to design curricula with innovations for each institution by paying attention to the priorities of the local community's geographical, sociological, and psychological aspects. The three components are adapted to the epidemic that afflicts the community.

The purpose of implementing a special conditions curriculum for education units is to create flexibility in learning materials in the midst of a disaster according to students' needs, potentials and conditions. This curriculum makes it easy for students to learn without carrying out learning according to structured demands while situations and conditions do not support it. Therefore, the government through the Minister of Education and Culture provides an offer with a curriculum with special conditions with a design choosing between three curriculum options: 1) using a comprehensive curriculum according to the National curriculum; 2) simplifying Core Competencies (Kompetensi Inti, KI) and Basic Competencies (Kompetensi Dasar, KD) in the curriculum-13; and 3) designing an independence-based curriculum (Makarim 2020).

The Ministry of Education and Culture in disaster conditions provides two alternative ways to apply the creative ideas of education stakeholders in developing the institution's curriculum. First, simplifying KI and KD in each lesson to emphasize core material and prerequisite material for studying advanced material (Makarim 2020a). Second, developing KI and KD independently based on the students' needs, potential, and learning environment. The independent curriculum embodies the independence of the institution that can produce distinguishing characters or characteristics from other educational institutions.

The origin of the basic word independent is oneself, an identity with the power of principles and self-commitment. In humanistic psychology, Carl Rogers calls it the word self as the essence of independence (Lynch and Sheldon 2017). Meanwhile, the origin of the word independent when quoting from the psychological dictionary is independence, meaning an attitude of confidence in determining decisions without depending on others (K. Kamil and Fathonah 2020). Self-confidence is an asset and strength in an individual's personality. The assets that can be managed properly will be the strengths and advantages of educational institutions (Parker 2006, 226).

Every educational institution with its advantages results from its ability to manage assets of time, thought, ability to manage problems, and bear all risks. Superior and advanced educational institutions must surpass all these without getting instructions and demands continuously until a goal is 
achieved. Independence also includes skills in completing, managing, and doing things (Parker 2006, 226). Therefore, if it is associated with the curriculum, the independent curriculum is a design of the subject structure produced by educational institutions by emphasizing differentiating values and paying attention to philosophical, juridical, psychological, sociological, scientific and technological developments.

\section{Independent Curriculum of al-Hikmah Boarding School Batu}

Based on the observations of researchers, Senior High School alHikmah Boarding School Batu uses curriculum-13, which was developed in the form of an independent curriculum for the Basic Leader Camp (BLC) program (Ariyanto 2020). The basic leader camp curriculum is a curriculum that forms students into leaders in various fields according to their respective potentials. In essence, the design of the institution's curriculum is oriented to meeting the personal needs of students (Interviu Kuntjoro, 2019). It means the humanization of education is a critical point for the institution's curriculum design by making students the subject of education.

There is an adjustment in the design of the basic leader camp curriculum program with the interests, talents, and potential of students through mapping abilities/potentials through the matriculation program at the beginning of the first academic year (Interviu Kuntjoro 2019). However, before matriculation activities, students have done academic, psychological, Quran, physical, and interviews tests during the selection to enter the institution (Administrator 2019). In addition, interviews are not only given to students, but parents are also interviewed to photograph their potential, interests, and talents (Interviu Kuntjoro 2019). The results of the two interviews became a big project that must be realized as a full-service agency to customers.

Not many educational institutions implement full and quality services to customers to get satisfaction values. Senior High School al-Hikmah Boarding School Batu always maintains the quality of education services through the curriculum in addition to other aspects, even in the conditions of the covid-19 pandemic. Still on the contrary, the pandemic condition is an opportunity to maximize the quality of independent curriculum services with the condition of other institutions that are hobbled in implementing the curriculum. Therefore, the curriculum based on the basic leader camp program is the right choice to be applied during the pandemic, as is the application at Senior High School al-Hikmah Boarding School Batu. 
The basic leader camp program is given for eight weeks or two months at the beginning of the school year for new students (Thalut 2019, 33). The program introduces the environment, culture, and means of character building for students (Ariyanto 2020). The basic leader camp curriculum design consists of 10 materials or activities with an accumulated percentage of all activities of $100 \%$. The ten basic leader camp materials or activities include: leadership 15\%, Quran 15\%, adab (behavior) 10\%, aqeedah and worship $15 \%$, learn how to learn (LHTL) for each subject $15 \%$, specialization $5 \%$, matriculation $20 \%, 5 \%$ orientation material, $5 \%$ state defense, and 5\% wisdom (Interviu Kuntjoro 2019). The explanation is as follows:

\section{Leadership}

The content of leadership material is a priority for Senior High School al-Hikmah Boarding School Batu as the slogan is "today's learner tomorrow's leader," which means now being a student and in the future being a leader. It is in line with the vision and mission that has been proclaimed related to the active contribution of students in global civilization through the realization of a generation with both personal and social behavior, and maximum achievement (Administrator 2019). The provision of leadership material at al-Hikmah Boarding School Batu emphasizes three things: physical, mental, and discipline, as an effort to form opportunities (Interviu Kuntjoro 2019), meaning the readiness of students to face the realities of life. Efforts to realize opportunities are carried out by leadership education in collaboration with the 3rd Cavalry Battalion of the Malang Regency army (Interviu Kuntjoro 2019). The results of leadership dedication are carried out on an ongoing basis through cleanliness to maintain in dormitories and schools as well as through the overall management of student councils and scouts by students.

\section{Quran}

The Quranic material in the basic leader camp curriculum is given from the start to students with the principle of building a sense of love for the Quran (Administrator 2019). The material taught at Senior High School al-Hikmah Boarding School Batu is not just reading, but memorizing and understanding content based on interpretations or studies delivered by scholars or moderate Muslim intellectuals. Concerning memorization activities in the material of the Quran, there is a target of at least two juz for three years or memorizing Surah alBaqarah and a maximum of fifteen juz or thirty juz if students can adapt 
with the density of activities. The minimum target is memorizing alBaqarah since it contains various knowledge of sciences, so that the Quran is a source of learning material in the classroom (Administrator 2019). While the study of the interpretation of the Quran is carried out every Friday or once a week at 07.30-09.00 WIB (7.30-9 AM) by Prof. M. Roem Rowi, an Islamic scholar in Quranic interpretation and Professor of Universitas Islam Negeri Sunan Ampel Surabaya with a scientific-based thematic interpretation study (Mim 2020).

\section{Adab}

Al-Hikmah Boarding School's high school efforts in forming students to have leadership characters, one of which is through the content of adab material with a portion of $10 \%$. There is a relevance of $a d a b$ with the vision and mission of the institution regarding the active contribution of students in global civilization (Administrator 2019). In addition, in shaping students' manners to actively contribute to global civilization, a study of the book Adab al'Âlim wa al-Muta'allim by KH. Hasyim Asy'ari, one of the founders of a prominent Indonesian Islamic organization, Nahdlatul Ulama'. Sheikh Said Barahmah taught the book on the primacy of knowledge and teaching by linking the example of the Prophet Muhammad PBUH and his companions in conducting education. It is conducted every Monday at 13.00 WIB (1 PM) through an online network that is not only followed by students, but teachers and employees follow it (Mim 2020).

\section{Aqeedah and Worship}

In the context of aqeedah, as the researchers observed that Senior High School al-Hikmah Boarding School Batu teaches moderate Islamic aqeedah by connecting Islamic values, nationality, and leadership (Interviu Kuntjoro 2019). It can be seen through the daily activities of students within 24 hours. The activity starts at 03.00 (3 AM) or a third of the night for qiyamul lail to carry out the tahajjud and witr prayers at the mosque in congregation and continue with the dawn prayer (Kuntjoro 2019). In addition, there are rituals of worship after dawn prayers such as reading the Quran, and other practices until 05.30 (5.30 AM). In addition, obligatory worship activities are also carried out in congregation followed by all students.

Students, teachers and employees carried out sunnah fasting worship to add to the blessings of life and dreams stated in the student's life proposal. The effort to get the blessing of learning is complemented by 
dhikr activities and prayer together in the routine worship activities of Senior High School al-Hikmah Boarding School Batu. Dhikr and prayer together are carried out incidentally when there is an obituary or good news such as the birth and marriage of siblings with prayers given by teachers and employees (Mim 2020). It is the momentum to foster a sense of kinship that exists through emotional-religious (Hanief and Hidayatullah 2021) ties at Senior High School al-Hikmah Boarding School Batu.

\section{Learn How To Learn (LHTL)}

It is a lifelong learning concept emphasizing that learning is not limited by space and time. Learning by focusing on reviewing the material that has been studied. Senior High School al-Hikmah Boarding School Batu teaches the concept of learning how to learn that covers: how to learn, the responsibility of students in learning, avoiding failure in learning, the ability to overcome problems in learning, and the ability of students to adapt to the demands of learning (Raingyuswaeko 2020).

6. Interests

Since their first entrance to the institution, students have carried out personal mapping of the intelligence, potential, interests and talents based on the initial tests related to academic, psychological, physical, Quran, and interviews of students and their guardians (Interviu Kuntjoro 2020). The principle of the institution is to facilitate what students need, not to provide what the institution has. The approach in developing students' specialization is independent learning or called self-directed learning (Chen, Chen, and Tsai n.d.). This concept is a comprehensive learning to accelerate the achievement of students' goals in the form of a life proposal. The institution provides opportunities for students to pursue and explore their choice of specialization which is carried out after the 'Asr prayer (Interviu Kuntjoro 2020).

\section{Matriculation}

Matriculation is given after the personal mapping of students regarding the strengths and weaknesses as well as strengths and weaknesses which are followed up with individual services according to the needs of students. Therefore, the orientation of this program is to complement the shortcomings and weaknesses of students as well as their strengths on tendencies and interests, considering that each participant has different skills (Interviu Kuntjoro 2020).

\section{Orientation Material}


Orientation material consists of the environmental and personal orientation of students. The environment in question is how students can be disciplined and responsible for all activities in dormitories and schools. Discipline is highly emphasized in carrying out worship, studying and exercising accompanied by responsibility for its implementation (Administrator 2019). While, students' personal orientation is related to their life in the future. Senior High School al-Hikmah Boarding School Batu facilitates the personal orientation of students in the form of a life proposal made at the end of the basic leader camp activity (Kuntjoro 2019). Life proposals are followed up with individual services by providing different materials from one another. Students have the opportunity to choose and add subject matter not studied. In addition, to support students' personal orientation, the institution facilitates it with a learning management system (LMS) containing basic and additional material made by the teacher for students to learn.

\section{Defend the Country}

This activity aims to increase love and foster responsibility towards the nation and state. Social responsibility as a civilized nation and moral responsibility to the state as a nation upholds the value of nationalism. Senior High School al-Hikmah Boarding School Batu collaborated with the third Cavalry Battalion of the Malang Regency army through the basic leader camp program (Administrator 2019).

\section{Al-Hikmah Material}

Based on the observations, the material on wisdom is given to students to provide insight into overall activities in schools and dormitories, including facilities, learning models, and the outputs produced by students. Senior High School al-Hikmah Boarding School Batu is an institution with outcome-based learning, so that basic leader camp activities are required to produce outcomes. These include diverse living cultures, culture of attitudes and learning motivation, leadership culture, calling for individual interests and talents, and life proposals with the approval of students and other people old (Thalut 2019, 35).

In addition, in introducing the profile of the institution, the Hikmah Apprenticeship Learning program was introduced. It is a collaboration between institutions and the world of work in filling school holidays. This program aims to increase the productivity of students in order to deepen their knowledge of expertise. The implementation of the program is the internships by grouping students according to their interests and 
expertise. For example, the IT group did an apprenticeship at PT. Infoglobal, software developer, owner of Bhre Work Photography, and so on. Meanwhile, the entrepreneur group studied and did an internship at the owner of the Citra Baby Shop, which is a supermarket with products for toddlers and has many branches. The group of doctors studied at the HRD of the hospital, and the group of public officials studied with the Regent of Banyuwanyi Azwar Anas by directly following their daily activities related to the community (al-Hikmah 2020).

\section{Figure 1}

Independent Curriculum of al-Hikmah Boarding School Batu Malang

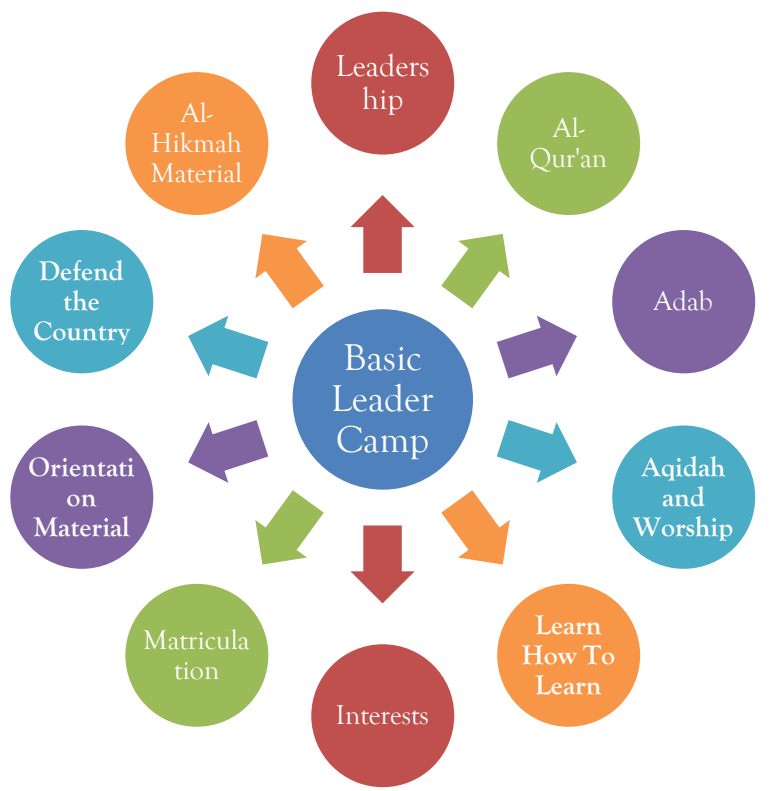

\section{Independent Curriculum Based on Islamic Values}

Independent as an attitude of not depending on others or standing firmly with self-principles without being influenced by others, meaning that there is self-autonomy in deciding or completing responsibilities (K. Kamil and Fathonah 2020). While the independent curriculum as a subject design for the autonomy of the educational institution itself that students must take from the beginning of admission to the end of entering the institution. It is in line with the curriculum used by Senior High School al-Hikmah Boarding 
School Batu which is the result of developing a school curriculum with the concept of curriculum independence namely the leadership curriculum (Administrator 2019).

The leadership curriculum as an independent curriculum for Senior High School al-Hikmah Boarding School Batu is in line with the established motto, namely Today's Learner Tomorrow's Leader (Purnomo 2021). The curriculum is an independent curriculum design produced by an institution aligned with the needs of the community and the development of science and technology. The independent curriculum has become a primary need for every institution with the institutional management model not only by providing knowledge and facilities, but also how the institution can meet the community's needs (Hidayatullah 2019).

Educational institutions indirectly with the Covid-19 pandemic condition must be adaptive to the curriculum as a foundation or curriculum as a menu for visitors when it is associated with the context of a restaurant. A varied food menu will attract buyers, as well as the curriculum without ignoring the value contained therein to be given to students. The independent curriculum contains Islamic values to complete the curriculum design to achieve the goals of national education as stipulated in the Law on the National Education System Number 20 of 2003 Chapter 2 Article 3. It stated to develop the potential of students to become human beings who believe and fear God, have good character, healthy, knowledgeable, capable, creative, independent, democratic, and responsible.

Based on the goals of national education, an independent attitude wants to be realized in the students' personality as a manifestation of selfpotential. To begin with, educators need an example, for instance the ability of educational institutions to develop independent curricula. The design of the independent curriculum preparation can be based on Islamic values to achieve the main goal of national education, namely personal faith and piety to God as in Senior High School al-Hikmah Boarding School Batu. Based on research results, the basic leader camp curriculum design contains Islamic values. The Islamic values in Ali Muhtadi's view consist of faith, worship and morals (Nurhabibah 2018, 213).

First, faith is defined by justifying in the heart, saying it verbally and practicing it in deeds. While Abdurrahman Assegaf defines faith as knowing, believing, and believing without the slightest doubt due to the emergence of knowledge and trust (Assegaf 2011,38). The value of faith is in line with the aqeedah education provided through the basic leader camp curriculum. 
Students of Senior High School al-Hikmah Boarding School Batu are given insight into moderate Islamic aqeedah by synergizing Islamic values, nationality, and leadership (Interviu Kuntjoro 2019).

Second, linguistic worship in Mohammad Daud Ali's view is defined as submission, obedience, and prayer (Nurhabibah 2018, 213). Worship is divided into two, namely mahdah worship (the provisions and implementers have been determined such as prayer, zakat, fasting, and hajj) and ghayr mahdah worship (the provisions and implementation are not set, for example studying, working hard, and helping each other). Senior High School alHikmah Boarding School Batu has included the value of worship in the independent basic leader camp curriculum. The value of worship in question is the activity of students for 24 hours in the form of worship mahdah and ghayr mahdah. This worship is emphasized by the disciplined attitude fostered in the implementation of worship to form an attitude of opportunity for students (Interviu Kuntjoro 2019).

Third, morality as a third value in Islam comes from the word khalaqa which means to create, with the plural word khulqun being temperament and character. Human behavior is referred to as morals, so that good behavior is good morals and vice versa (Nurhabibah 2018, 214). Senior High School alHikmah Boarding School Batu has provided students with an independent basic leader camp curriculum through leadership, state defense, and wisdom materials related to the culture of everyday life in institutions and dormitories.

\section{The Relevance of the Independent Curriculum to the Curriculum for Special Conditions of Covid-19}

Independence is the attitude of not depending or expecting others. Independence is an effort to mobilize all abilities in thinking and acting and controlling it without depending on others (Boe et al. 2018). Carl Rogers calls independence with the term self meaning oneself as the core of one's independence (Lynch and Sheldon 2017). In psychology, the origin of the word independence is independence, namely a person's ability to make decisions accompanied by an attitude of confidence without depending on others (K. Kamil and Fathonah 2020).

Like God's creatures, from being in the womb until he died in his own state. Creative ideas that arise on one's own initiative, even though in the end they must collaborate to make it concrete in the form of creative products. 
Independence in education is a source of individual and group strength that can lead people or institutions to become confident in fulfilling their hopes and dreams. The concept of independence is often associated with autonomy, which means freedom to choose, govern, control, and determine one's own personality (Iftene 2014). It is relevant to education and its components; if autonomy is applied, it can result in the institution's competitiveness.

Autonomy in independence has a relationship with personal and group ego. The formation of a personal ego makes a person have a strong identity that can develop individuality by standing up straight, strong, without being shaken or influenced (Bonneville-Roussy, Vallerand, and Bouffard 2013). A person's autonomy has the opportunity to develop thoughts, control feelings and actions freely in building an idea and overcoming doubts. It contains an element of responsibility as a guide in acting. Therefore, if an educational institution has its own autonomy, then the institution can form the characteristics of an institution to differentiate it from others (distinction).

One component of education as the heart of educational institutions is the curriculum. A set of subjects that students must take from entering to leaving school is called the curriculum as a field of study (Iftene 2014). Schools have the authority to design and develop curricula based on school autonomy as the concept of school-based management (SBM). Schools have full authority in managing human resources, funding sources, and other components within the scope of national education (OECD 2011). This authority serves as school autonomy in the provision of education as a new paradigm in education as well as realizing the implementation of the concept of decentralization of educational institutions.

The concept of decentralization of education and its implementation has been regulated by Law Number 32 of 2004 concerning Regional Government and Number 33 of 2004 concerning Central and Regional Financial Balance (change in Laws Number 22 and Number 25 of 1999). Educational institutions in each region have the authority to regulate and develop educational components according to national education standards in implementing decentralization policies including the curriculum. Decentralization opens opportunities for education to innovate and develop curriculum to the fullest according to regional potential, while the central government controls in the application of decentralization (Hidayat and Machali 2012, 53).

Independent curriculum as a form of educational reform to improve the quality of institutions. The school's independence in curriculum 
preparation is in line with the SBM concept. Schools can independently explore potential, develop curriculum material/content, and are able to be accountable to the community and the government (Fucci and Cavaletto 2012). Through this step, the skills of managing institutions can grow and develop due to two factors, namely discipline and group commitment (Lynch and Sheldon 2017). Indirectly, the independent curriculum is a school effort in compiling the institution's superior competencies according to the needs of the community and the development of science and technology

The COVID-19 pandemic has encouraged the development of independent curricula in educational institutions. Independent curriculum is an alternative to using a curriculum in pandemic conditions based on the Decree of the Minister of Education and Culture number 719 of 2020 on Guidelines for Curriculum Implementation in Education Units in Special Conditions. The Ministry of Education and Culture provides options for flexible use of the curriculum in learning according to the needs and conditions of students. Curriculum choices consist of curriculum-13, emergency curriculum (in special conditions), and independent curriculum (Makarim 2020, 18).

The choice of implementing an independent curriculum in a pandemic is the right decision for educational institutions. The Minister of Education and Culture provides suggestions for an independent curriculum as the best option with the recommendation of the three curriculum options offered (Makarim 2020). The independent curriculum is considered to provide flexibility for institutions in adapting local potential to student learning. Independent curriculum design is based on the priority needs of the community (students and parents) and is oriented towards achieving the institution's vision and mission without ignoring central government policies. Through the independent curriculum, schools have the authority to freely and develop the material taught to students (Makarim 2020).

As the results of the Minister of Education and Culture survey on schools in West Nusa Tenggara, 70\% of teachers and heads of education offices in Mataram City want freedom in formulating curriculum and implementing learning. This desire is to accommodate the potential and human resources of each institution. For example in basic education institutions, $20 \%$ of students only have internet access, which is certainly very problematic if fully implemented online learning. Therefore, the independent curriculum is a solution for teachers to compose teaching materials freely without requiring large internet access (Makarim 2020). 
Based on these data, it is crucial to have an independent curriculum to stabilize the learning in special conditions and create the identity of the institution's characteristics.

Figure 2

The Urgency of Independent Curriculum During the Covid-19 Pandemic

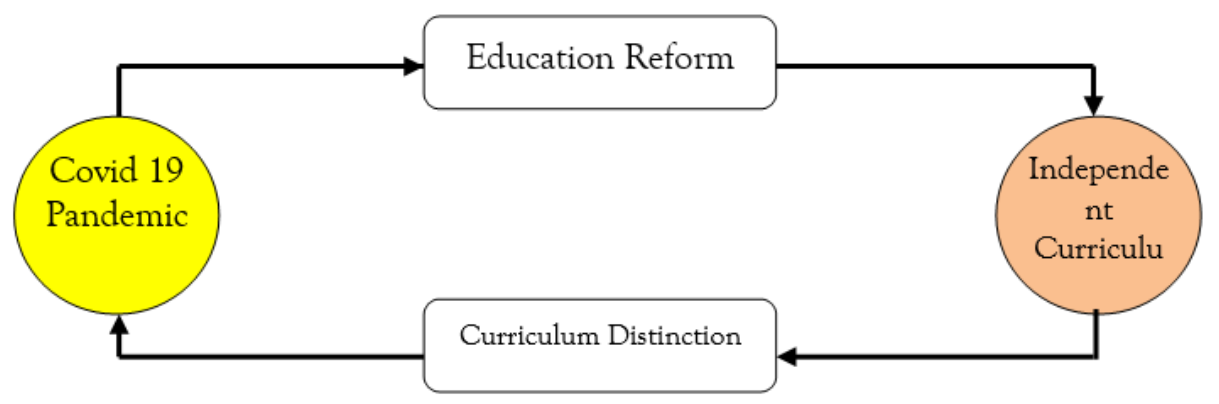

\section{Characteristics and Principles of Independent Curriculum Design}

The independent curriculum has distinguishing characteristics from other curricula, considering that the curriculum is a strength in making educational institutions competitive and competent in certain fields of expertise or scholarship. Field competencies emerge based on scientific buildings embedded in the foundation of the institution as the definition of curriculum is the foundation of education. The independent curriculum encourages the birth of student expertise based on the concentration of knowledge learned and the developed potential. There is a link between the potential and independence of the curriculum as a characteristic of an independent curriculum. Therefore, it is necessary to understand its characteristics based on the concept of independence (Berbrayer 2013).

First, the ability to make decisions and take initiative in solving problems. Every institution can certainly have complaints in applying national education standards, especially on curriculum. The problems cover three standards: content standards, processes, and graduate competencies. The three standards affect the quality of the learning process and the students' competence after graduation (Syafaruddin 2017, 84). Therefore, institutions need to pay attention to the processes that determine the success of the curriculum. The problems are usually related to the planning, implementation, evaluation, and results of curriculum implementation. Meanwhile, the role of the institution is to take the initiative and decision 
steps in conducting independent curriculum innovations to relevant curriculum content to the life concerns of students (Syafaruddin 2017, 45).

Second, the existence of a competitive desire to improve the institution's quality. The desire comes from a deficiency. Educational institutions are difficult to develop when vital aspects such as the curriculum are not given free space, movement, and expression as needed. Curriculum development will be hampered by the power of innovation, imagination, and inspiration when there is a suppression of development creativity. It causes the curriculum to become materialistic since it is trapped in stagnation or static conditions (Palupi 2018). Therefore, the curriculum loses substance and character. The emergence of a desire to develop an independent curriculum encourages the birth of an institutional mentality to have competitiveness and excellence.

Third, be responsible for the overall curriculum development. The curriculum is responsible for assisting students in developing all their potential, not the other way around fostering the learning process. The curriculum is fully responsible for student's entire process and learning outcomes both inside and outside the school (Syafaruddin 2017, 15-16). Some institutions sometimes blame the curriculum when there are social deviations of students or failure to implement it under the pretext of the fault of the central government. Whereas the concept of decentralization has been implemented, and institutions have the authority to develop the central curriculum independently and take responsibility for its overall implementation.

Fourth, the ability to criticize and self-assessment. The curriculum struggles with thoughts of various interests with relative truth and can be criticized (Palupi 2018). The curriculum requires criticism to straighten and perfect the results of human thinking from irrational to rational and empirical. The independent curriculum openly provides a great opportunity for criticism and self-assessment to make improvements to meet the community's needs.

Fifth, have confidence in creation and work. The fifth characteristic is the key as an independent curriculum. Copyrights and works are one's best contribution in taking innovative steps to produce an independent curriculum based on the characteristics of the institution's curriculum.

Meanwhile, in implementing the independent curriculum, it is necessary to pay attention to the principles of its application to strengthen the identity of the innovation results. The principle of an independent 
curriculum is in line with the concept of decentralization in education. Education decentralization provides for developing creativity and managing potential. Four independent curriculum principles include autonomy, flexibility, participatory, and initiative (Hidayat et al. 2012, 56).

First, curriculum autonomy is the right and authority of the institution in compiling, managing and developing the curriculum without ignoring the juridical basis. Second, the flexibility of the curriculum provides opportunities for the development of material/content design to be adapted to local and institutional potential, both regarding teaching resources and student input. Therefore, the independent curriculum design adheres to human resources and the institution's potential.

Third, participatory as a guide in developing an independent curriculum. It means the institution is open to input from various parties, the education stakeholders. The participatory principle in the independent curriculum builds shared and democratic responsibility for the agreement of a decision. Thus, there is a sense of belonging to be beaten together and fought for with various efforts in order to achieve the goals set.

Fourth, the initiative towards an independent curriculum means that institutions with dynamic conditions need to take innovative steps in curriculum development by mobilizing all potentials to explore, discover, and develop creativity and independent curriculum innovation. It is done without thinking long by moving quickly to take the initiative to maximize the potential in curriculum development.

Figure 3

Characteristics and Principles of Independent Curriculum

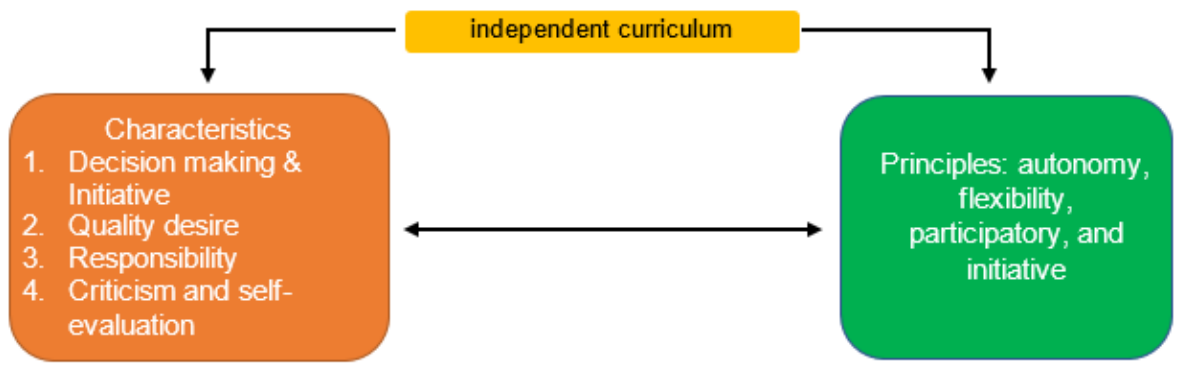




\section{Conclusion}

Senior High School al-Hikmah Boarding School Batu is an educational institution that applies a humanistic approach to the system and learning process, including the curriculum used. The humanistic approach is in line with the concept of independent learning and the curriculum for special conditions based on government regulations, one of which is an independent curriculum based on Islamic values. This curriculum gives students the freedom to plan, organize, choose learning resources and determine the assessment of learning outcomes while still paying attention to the teacher's guidelines. In addition, students have a great opportunity to develop their potential, interests and talents through escorting and following up on life proposals prepared at the beginning of school entry. Efforts to realize ideals are strengthened through the spirituality and mentality of students who are nurtured from the beginning and are sustainable. Building students' disciplined attitudes in obligatory and sunnah worship and maintaining physical condition through state defense education in the basic leader camp curriculum, which is followed up with exercise routines. The synergy of the spiritual, intellectual, and mental values of students' leadership becomes a unity built into their identity as capital in realizing their goals.

\section{References}

Administrator. 2019. "Tahfidz Quran di Al-Hikmah Boarding School Batu." https://pesantrentahfidzquran.com/tahfidz-quran-di-al-hikmahboarding-school-batu/.

Affany, Ma'mun. 2019a. Interviu Edy Kuntjoro. Kegiatan 24 Jam Siswa AlHikmah Boarding School Batu. Batu. https://www.youtube.com/watch?v=rmyggGwpu-c.

Affany, Ma'mun. 2019b. Interviu Edy Kuntjoro. Kurikulum Kepemimpinan di AlHikmah Islamic Boarding School Batu. Batu. https://www.youtube.com/watch? $v^{=}=\mathrm{cFJKr6U5Y4k.}$

Affany, Ma'mun. 2020. Interviu Edy Kuntjoro. Kurikulum di Al-Hikmah Boarding School Batu https://www.youtube.com/watch?v=1LBpjRm1t1s.

Ariyanto, Eko (Waka Kesiswaan \& Sarpras). 2020. "Tak Pernah Berhenti Berkreasi Di Musim Pandemi.” 
https://boarding.alhikmahsby.sch.id/baca/tak-pernah-berhentiberkreasi-di-musim-pandemi.

Assegaf, Abdurrahman. 2011. Filsafat Pendidikan Islam: Paradigma Baru Pendidikan Hadhari Berbasis Integratif-Interkonektif. Jakarta: Raja Grafindo Persada.

Bakri, Masykuri. 2013. Metodologi Penelitian Kualitatif: Tinjauan Teoritis dan Praktis. Surabaya: Visipress Media.

Berbrayer, David. 2013. "Depression and Functional Independence, Education, and Employment in Adults with Spina Bifida-Case Control Quantitative Study." PMER 5: S200-S200.

DOI: https://doi.org/10.1016/j.pmrj.2013.08.278.

Bird, Eleanor et al. 2020. The Ethics of Artificial Intelligence: Issues and Initiatives. European Parliamentary Research Service.

Boe, Ole, Reidar SÃofvenbom, Rino Bandlitz Johansen, and Robert Buch. 2018. "The Relationship between Self-Concept, Self-Efficacy, and Military Skills and Abilities." International Journal of Learning, Teaching and Educational Research 17(10): 18-42.

DOI: https://doi.org/10.26803/ijlter.17.10.2.

Bonneville-Roussy, Arielle, Robert J. Vallerand, and Thérèse Bouffard. 2013. "The Roles of Autonomy Support and Harmonious and Obsessive Passions in Educational Persistence." Learning and Individual Differences 24: 22-31.

DOI: https://doi.org/10.1016/j.lindif.2012.12.015.

Chen, Chang-Hua, Ken-Zen Chen, and Hsiao-Feng Tsai. "Did Self-Directed Learning Curriculum Guidelines Change Taiwanese High-School Students' Self-Directed Learning Readiness?" The Asia-Pacific Education Researcher.

DOI: https://doi.org/10.1007/s40299-021-00582-w.

Fucci, Stefania, and Giulia Maria Cavaletto. 2012. "Educational Choices of the Elites. Autonomy and Responsibility of Italian and Foreign Children Between Family and School | Elsevier Enhanced Reader." Procedia and Behavioral Sciences: 4990-94.

Hanief, Muhammad, and Muhammad Fahmi Hidayatullah. 2021. "Internalization of Character Values Based on Spiritual Intellegence at 
SD Islam Bani Hasyim Malang Regency." Conciencia 21(1): 37-48. DOI: https://doi.org/10.19109/CONCIENCIA.V21I1.8576.

Hidayat, Ara; Machali, Imam. 2012. Pengelolaan Pendidikan: Konsep, Prinsip, dan Aplikasi Dalam Mengelola Sekolah dan Madrasah. Yogyakarta: Kaukaba.

Hidayatullah, Muhammad Fahmi. 2019. "Model Pendidikan Karakter Sepenuh Hati pada Siswa Madrasah Ibtidaiyah.” Elementeris: Jurnal Ilmiah Pendidikan Dasar Islam 1(2): 19-28.

DOI: https://doi.org/10.33474/ELEMENTERIS.V1I2.4972.

al-Hikmah, Yayasan. 2019. "Profil SMA Al-Hikmah Boarding School Batu." https://boarding.alhikmahsby.sch.id/baca/profil-sma-al-hikmahboarding-school-batu.

al-Hikmah, Yayasan. 2020. "Hikmah Apprenticeship Learning." https://boarding.alhikmahsby.sch.id/baca/hikmah-apprenticeshiplearning.

Iftene, Cristi. 2014. "Educational Systems' Autonomy. Facts and Analysis." Procedia - Social and Behavioral Sciences 142: 47-53.

DOI: https://doi.org/10.1016/J.SBSPRO.2014.07.586.

Kamil, Irfan. 2020. "Dirjen Dikti: 70 Persen Mahasiswa Dan Dosen Nilai Pembelajaran Daring Lebih Baik." https://spada.kemdikbud.go.id/berita/dirjen-dikti-70-persenmahasiswa-dan-dosen-nilai-pembelajaran-daring-lebih-baik.

Kamil, Krishna, and Nadya Fathonah. 2020. "The Effect of Independence, Integrity, Professionalism, and Professional Skepticism on the Accuracy of Giving Audit Opinion (The Case of Audit Board of the Republic of Indonesia)." Atlantis Press 127: 5-10.

DOI: https://doi.org/10.2991/AEBMR.K.200309.002.

Kemendikbud. 2020. Kepmendikbud Nomor 719/P/2020 Tentang Pedoman Pelaksanaan Kurikulum Pada Satuan Pendidikan Dalam Kondisi Khusus. https://www.kemdikbud.go.id/main/blog/2020/08/kemendikbudterbitkan-kurikulum-darurat-pada-satuan-pendidikan-dalam-kondisikhusus.

Kunjcoro, Edy. 2020. "Konsep Dasar Self Directed Learning." https://sekolahpesantren.id/konsep-dasar-self-directed-learning/. 
Kuntjoro, Interviu Edy. 2019. "Al-Hikmah Batu Bebaskan Siswa Pilih Jadwal Sendiri.” https://sekolahpesantren.id/al-hikmah-batu-bebaskan-siswapilih-jadwal-sendiri/.

Lynch, Martin F., and Kennon M. Sheldon. 2017. "Conditional Regard, SelfConcept, and Relational Authenticity: Revisiting Some Key Rogerian Concepts Cross-Culturally, Through Multilevel Modeling:” Journal of Humanistic Psyichology 60(2): 168-86.

DOI: https://doi.org/10.1177/0022167817696842.

Makarim, Nadiem Anwar. 2020a. Penyesuaian Kebijakan Pembelajaran Di Masa Pandemi COVID-19. Jakarta.

Makarim, Nadiem Anwar. 2020b. "Sekolah Perlu Terapkan Kurikulum Mandiri Saat Pandemi - Bukan 'Kurikulum Darurat' Anjuran Mendikbud Nadiem.” https://theconversation.com/sekolah-perluterapkan-kurikulum-mandiri-saat-pandemi-bukan-kurikulum-daruratanjuran-mendikbud-nadiem-144742.

Miles, M.B, Huberman, A.M, dan Saldana, J. 2014. Qualitative Data Analysis, A Methods Sourcebook, Edition 3. USA: Sage Publications. Terjemahan Tjetjep Rohindi Rohidi. Jakarta: UI-Press.

Mim, Saiful Hadi (Kepala Asrama). 2020. "Silaturrahim Online Menggelorakan Semangat Juang Guru." https://boarding.alhikmahsby.sch.id/baca/silaturrahim-onlinemenggelorakan-semangat-juang-g.

Moleong, Lexy J. 2000. Metode Penelitian Kualitatif. Bandung: PT. Remaja Rosda Karya.

Nasri, Mohamad Mohamad, N Halim, and L Talib. 2020. "Self-Directed Learning Curriculum: Students' Perspectives of University Learning Experiences." Malaysian Journal of Learning and Instruction 17(2): $227-$ 51.

DOI: https://doi.org/10.32890/mjli2020.17.2.8.

Nurhabibah, Nurhabibah. 2018. "Penanaman Nilai-Nilai Keislaman Dalam Keluarga di Lingkungan Lokalisasi Pasar Kembang Yogyakarta.” Tadris 13(2): 211-18.

DOI: https://doi.org/10.19105/tjpi.v13i2.1708.

OECD. 2011. Pisa in Focus School Autonomy and Accountability: Are They 
Related to Student Performance?

DOI: https://doi.org/10.1016/j.anbehav.2013.11.030.

Palupi, Dyah Tri. 2018. "What Type of Curriculum Development Models Do We Follow? An Indonesia's 2013 Curriculum Case.” Indonesian Journal of Curriculum and Educational Technology Studies 6(2): 98-105.

DOI: https://doi.org/10.15294/IJCETS.V6I2.26954.

Parker, Deborah. 2006. Menumbuhkan Kemandirian dan Harga Diri Anak. Jakarta: Prestasi Pustakaraya.

Purnomo, Muhammad. 2021. "Belajar Sepanjang Hayat." https://boarding.alhikmahsby.sch.id/baca/belajar-sepanjang-hayat.

Raingyuswaeko. 2020. Basic Leader Camp - Learn How to Learn - al-Hikmah Boarding Batu.

Batu. https://www.youtube.com/watch? $v=4 B i 8 Z 2 x S H e o$.

Razawi, Nurul Amilin et al. 2011. 'Students' Diverse Learning Styles in Learning English as a Second Language." International Journal of Business and Social Science 2(19): 179-86.

DOI: https://doi.org/10.30845/ijbss.

SMRC. 2020. Asesmen Publik Tentang Pendidikan Online di Masa Covid-19. Jakarta. https://saifulmujani.com/asesmen-publik-tentang-pendidikanonline-di-masa-covid-19/.

Sugiono, Sugiono. 2016. Metode Penelitian Pendidikan (Pendekatan Kuantitatif, Kualitatif Dan R $\mathcal{E} D$ ). Bandung: Alfabeta.

Suradi, Ahmad, Qolbi Khoiri, Nilawati Nilawati, and Nopian Gustari. 2021. "Designing The Pesantren Curriculum to Counter Radicalism: Study on Pondok Pesantren Wali Songo Ngabar Ponorogo." ULUL ALBAB Jurnal Studi Islam 22(1): 49-68.

DOI: https://doi.org/10.18860/UA.V22I1.11212.

Syafaruddin; Amiruddin. 2017. Manajemen Kurikulum. Medan: Perdana Publishing.

Tempo.co. 2020. "Mendikbud: Sekolah Bebas Pilih Kurikulum Yang Sesuai." https://nasional.tempo.co/read/1375746/mendikbud-sekolah-bebaspilih-kurikulum-yang-sesuai/full\&view=ok. 
Thalut, Mohammad. 2019. "SMA Al-Hikmah Boarding School Batu." prezi.com.

worldbank. 2021. "Governance \& Institutions COVID-19 Response Resources."

https://www.worldbank.org/en/topic/governance/brief/governanceinstitutions-covid-19-response-resources. 